\title{
Quantification of loss in oilseed rape yield caused by delayed sowing date in a Mediterranean environment
}

\section{M. Ângelo Rodrigues, Sandra Afonso, Nelson Tipewa, Arlindo Almeida \& Margarida Arrobas}

To cite this article: M. Ângelo Rodrigues, Sandra Afonso, Nelson Tipewa, Arlindo Almeida \& Margarida Arrobas (2019) Quantification of loss in oilseed rape yield caused by delayed sowing date in a Mediterranean environment, Archives of Agronomy and Soil Science, 65:12, 1630-1645, DOI: $10.1080 / 03650340.2019 .1572119$

To link to this article: https://doi.org/10.1080/03650340.2019.1572119

Accepted author version posted online: 21

Jan 2019.

Published online: 05 Feb 2019.

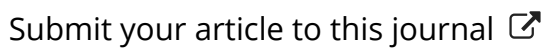

山 Article views: 77

View related articles

View Crossmark data $\nearrow$ 


\title{
Quantification of loss in oilseed rape yield caused by delayed sowing date in a Mediterranean environment
}

\author{
M. Ângelo Rodrigues (1Da, Sandra Afonso ${ }^{a}$, Nelson Tipewa ${ }^{b}$, Arlindo Almeida ${ }^{a}$ \\ and Margarida Arrobas (D) \\ ${ }^{a}$ Centro de Investigação de Montanha (CIMO), Instituto Politécnico de Bragança, Bragança, Portugal; ' Instituto \\ Politécnico do Kwanza Sul, Sumbe, Angola
}

\begin{abstract}
Rapeseed acreage has been increasing fast in the last few decades and cultivated areas have expanded into lower latitudes because of the high value of its seed. This work evaluates the effect of date of sowing and nitrogen $(\mathrm{N})$ fertilization on crop productivity and $\mathrm{N}$ use efficiency in a Mediterranean environment. The experiment was arranged in a split-plot design with the dates of sowing as the main-plots and $\mathrm{N}$ rates the sub-plots. Rapeseed recovered 128 to $212 \mathrm{~kg} \mathrm{~N} \mathrm{hm}^{-2}$ before top-dress $\mathrm{N}$ application in late winter if sown before the last week of September. Seed yield was very dependent on the date of sowing, varying from 3.4 to $6.2 \mathrm{Mg} \mathrm{hm}^{-2}$ on the first sowing date in September to 0.3 to $1.0 \mathrm{Mg} \mathrm{hm}^{-2}$ on the last sowing date in November. The daily loss in seed production was $68.9 \mathrm{~kg} \mathrm{hm}^{-2}$ (or 482.3 $\mathrm{kg} \mathrm{hm}^{-2}$ per week) or $1.53 \%$ (or $10.7 \%$ per week). $\mathrm{N}$ rate significantly increased seed yield within each sowing date but did not allow latesowed plants to regain the productivity levels of those sown earlier. Apparent $\mathrm{N}$ recovery and agronomic $\mathrm{N}$ efficiency were particularly dependent on the growing conditions associated to different sowing dates.
\end{abstract}

\section{ARTICLE HISTORY}

Received 28 July 2018

Accepted 16 January 2019

\section{KEYWORDS}

Brassica napus; nitrogen fertilization; dates of sowing; nitrogen use efficiency; seed oil content; seed yield

\section{Introduction}

Rapeseed (Brassica napus L.) is the third most important oilseed crop in the world, just behind palm tree and soybean, and is the one that grows at the fastest rate. World production of rapeseed has been above $70 \times 10^{6}$ t since 2013 and has doubled in the last 20 years (FAOSTAT 2018). The increasing interest in this crop is due to the high price of seed, which is due to the quality of the edible oil of CANOLA (CANadian Oil, Low Acid) or double-zero (low glucosinolate/low erucic acid) varieties (Guerrero 1999), the importance of seedcake in livestock feeding (Berrocoso et al. 2015; Kuai et al. 2016) and the excellent properties of the oil for biodiesel production (Körbitz 1995; Pinzi et al. 2011; Leiva-Candia et al. 2013). Rapeseed is also an important crop to the agroecosystems since it is a good preceding crop for cereals (Sieling and Christen 1997) and a valuable catch crop able to reduce nitrate leaching during winter (Dejoux et al. 2000; Rossato et al. 2001).

Rapeseed is well adapted to cool temperate climates. The greatest ecological potential to produce rapeseed seems to be found in Europe, where national seed production can easily exceed $4000 \mathrm{~kg} \mathrm{ha}^{-1}$, in countries such as Belgium, Germany or France (FAOSTAT (Food and Agriculture Organization of the United Nations) 2018). In warmer climates, such as in southern Europe, the crop loses importance since the growing conditions are less favourable, mainly due to the reduction of precipitation and the increase of temperature in the spring and early summer. It has been shown

CONTACT M. Ângelo Rodrigues angelor@ipb.pt $\Theta$ Centro de Investigação de Montanha (CIMO), Instituto Politécnico de Bragança, Campus de Santa Apolónia, Bragança, Portugal

() 2019 Informa UK Limited, trading as Taylor \& Francis Group 
that drought stress is one of the major constraints on the development of rapeseed in arid and semi-arid environments (Norouzi et al. 2008; Din et al. 2011). However, given such favourable seed prices, there has been increased interest in this crop in southern Europe, in countries such as Spain, Italy, Greece or Portugal. Portugal has no tradition of producing oilseed rape, although some research has indicated that the crop could be satisfactorily grown here (Rodrigues et al. 2010, 2011, 2013 , 2014). In recent years some producers have started growing rapeseed with profitable results, although with a high inter-annual variation mainly depending on weather conditions.

To grow rapeseed in lower latitudes it must be borne in mind that rapeseed can be differentiated into winter or spring forms, with the latter being more important as one moves to colder climates (Bouchet et al. 2016). In the northern hemisphere, the growing cycle of winter forms begins in August by using varieties with high vernalization requirements (Guerrero et al. 1999; Wang et al. 2011). In Mediterranean climates, as in southern Europe, the winter growing cycle is the only feasible in rainfed conditions, given the scarcity of precipitation and the high temperatures from mid-spring (Rodrigues et al. 2010, 2013). In arid and semi-arid environments, rapeseed can also be grown in irrigated areas (Taylor and Smith 1992; Ozer et al. 2003; Hamzei 2011; Hamzei and Soltani 2012; Sepaskhah and Tafteh 2012), which is currently seen as a crop of strong potential for expansion (Hamzei and Soltani 2012).

Taking into account the economic importance of rapeseed, several aspects of cropping have been regularly studied, such as cultivar adaptation (Ozer 2003; Rodrigues et al. 2010, 2013, 2014; Takashima et al. 2013), response to $\mathrm{N}$ fertilizers (Rathke et al. 2005; Németh et al. 2009; Rodrigues et al. 2010; Li et al. 2015; Kuai et al. 2016; Gu et al. 2017), date of sowing (Johnson et al. 1995; Ozer 2003; Rodrigues et al. 2013; Sieling et al. 2017), and planting density (Leach et al. 1999; Zang et al. 2012; Wang et al. 2015; Kuai et al. 2016). However, the performance of the crop when grown in warmer and drier climates as a response to such cropping conditions is less well known. In Europe, the expansion of the crop into the south needs to be accompanied by more research evaluating the performance of the species in the face of new abiotic and biotic stresses.

Under Mediterranean conditions, an aspect that seems relevant to the final crop yield is sowing date. With reference to other winter crops, particularly small grains, sowing date can potentially occur from late summer, after the first autumn rains, until the end of the autumn, when the low temperatures limit seed germination. However, seed companies are advising for an early sowing in the autumn as a mean of promoting the establishment of a vigorous rosette and previous studies have pointed in the same direction (Rodrigues et al. 2013). However, the extent to which the date of sowing affects crop production under Mediterranean conditions is still not fully understood.

$\mathrm{N}$ is another important ecological factor that always deserves attention due to its potential to increase crop yield and to cause environmental damage (Havlin et al. 2014). Rapeseed is a crop often referred to as having high $\mathrm{N}$ requirements but also characterized by low $\mathrm{N}$ use efficiency (Pouzet 1995; Rathke et al. 2006; Németh et al. 2009; Bouchet et al. 2016). Studies from Turkey (Ozer 2003) have shown that rapeseed responded by up to $160 \mathrm{~kg} \mathrm{~N} \mathrm{ha}^{-1}$ in a field trial where maximum seed yield was about $1200 \mathrm{~kg} \mathrm{ha}^{-1}$. In Germany, Rathke et al. (2005) reported an increased response of oilseed yield by up to $240 \mathrm{~kg} \mathrm{~N} \mathrm{ha}^{-1}$, from experiments where the most productive plots reached almost $5 \mathrm{t} \mathrm{ha}^{-1}$ of seed. From field trials carried out in France, Fismes et al. (2000) reported apparent $\mathrm{N}$ recoveries varying between $36 \%$ to $53 \%$. In a review of $\mathrm{N}$ management and $\mathrm{N}$ efficiency of winter oilseed rape, Rathke et al. (2006) emphasized the need for integrating $\mathrm{N}$ management strategies, which include soils, crop rotations and $\mathrm{N}$-supply, to enhance productivity of winter oilseed rape and the efficient use of $\mathrm{N}$. More recently, also in a review of $\mathrm{N}$ use efficiency in rapeseed, Bouchet et al. (2016) focused on the complexities of improving rapeseed yield, with overlapping phases of $\mathrm{N}$ uptake and remobilization during the crop cycle, and discusses the genetic diversity of the crop and breeding strategies as a mean of improving $\mathrm{N}$ use efficiency. Thus, taking into account that crop $\mathrm{N}$ requirements usually depend on the potential of the agrosystems to produce phytomass, the response of the crop to $\mathrm{N}$ fertilization and $\mathrm{N}$ use efficiency, when grown in Mediterranean conditions, also justifies further study. 
Thus, in view of the above, the objective of the study was to assess the effects of the sowing date on growth and yield of oilseed rape and how $\mathrm{N}$ applied as a top-dressing can compensate for the loss of biomass accumulation that the plants of the later sowings usually experience. This was achieved by a three-year trial where several dates of sowing were tested by evaluating the crop biomass produced during the autumn and winter. At the end of the winter, different $\mathrm{N}$ rates were applied as top-dressing to assess how additional $\mathrm{N}$ can compensate for delays in the vegetative development and influence final seed yield and oil content.

\section{Materials and methods}

The experiments were carried out in Santa Apolónia farm $\left(41^{\circ} 47^{\prime} 47.9^{\prime \prime} \mathrm{N} ; 6^{\circ} 45^{\prime} 59.8^{\prime \prime} \mathrm{W} ; 678 \mathrm{~m}\right.$ altitude above sea level) NE Portugal. The region benefits from a Mediterranean type climate with some Atlantic influence. Average annual temperature and precipitation of the region in the 1981-2010 period were, respectively, $12.7^{\circ} \mathrm{C}$ and $772.8 \mathrm{~mm}$. Mean monthly temperature and precipitation in the period 1981-2010 and values recorded during the experimental period are shown in Figure 1.

The field trials were carried out on an experimental plot which had been cultivated with a mixture of small grasses and legumes whose biomass was used for hay. During the three years of trials the experimental plots rotated on this parcel of land to avoid the residual effect of the fertilization of the previous years since different rates of $\mathrm{N}$ were applied in the experimental plots. Thus, the preceding crop was always the mixture of small grasses and legumes.

The soil of the plot where the field trials were carried out is classified in the group of Eutric Cambisols (IUSS Working Group WRB 2014). The soil is loamy textured (54\% sand, $25 \%$ silt, and $21 \%$ clay), slightly acid ( $\mathrm{pH}=6.0)$ and low in organic carbon $\left(0.8 \mathrm{~g} \mathrm{~kg}^{-1}\right.$, Walkley-Black). Phosphorus and potassium levels were respectively high and very high as determined by Egner-Rhiem method. Both exchangeable calcium and magnesium were high, respectively, 11.8 and $6.4 \mathrm{cmol}_{\mathrm{c}} \mathrm{kg}^{-1}$ as determined by the ammonium acetate method.

The experiments were arranged in a split-plot design since the operations involved make it difficult to handle all the factor combinations in the same manner. The dates of sowing were assigned to main plots in a randomized complete block with three replications. $\mathrm{N}$ rates were assigned to subplots within each main plot (Little and Hills 1978). In 2014 and 2015, the crop was sown on three different dates and in 2016 the sowing dates were four (Table 1). In 2014 three

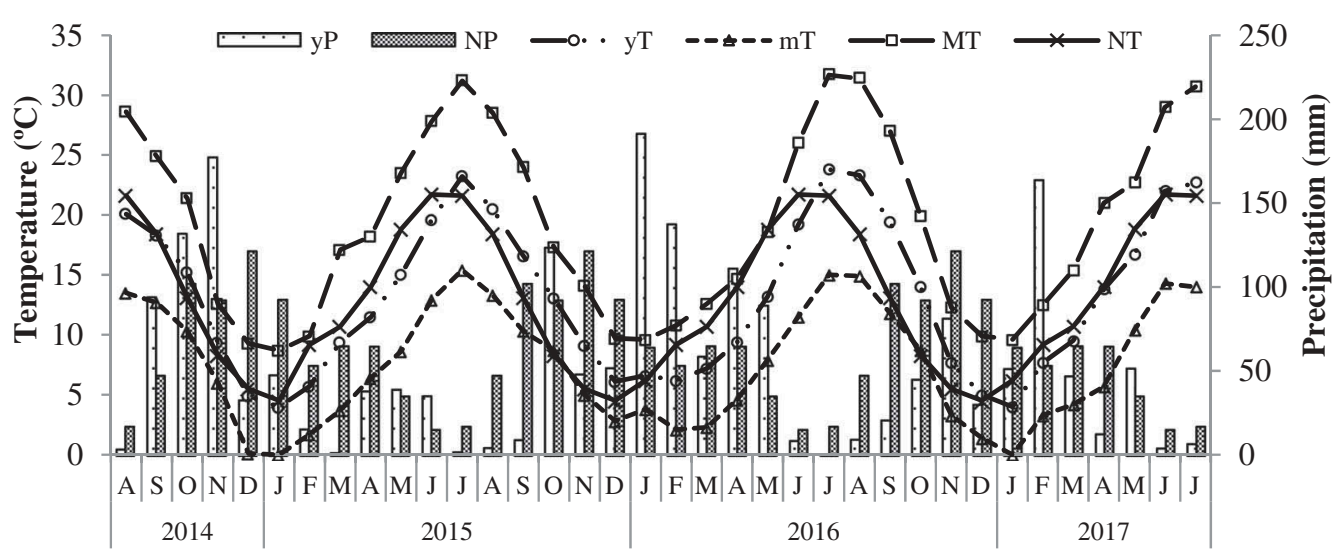

Figure 1. Monthly precipitation during the experimental period (yP) and in a period of thirty years 1981-2010 (NP) and mean monthly temperature $(\mathrm{yT})$, mean minimum temperature $(\mathrm{mT})$ and mean maximum temperature (MT) during the experimental period and mean monthly temperature in the period 1981-2010 (NT). 
Table 1. Dates of sowing and $\mathrm{N}$ rates in the field trials corresponding to the growing seasons of 2014-2015, 2015-2016 and 2016-2017.

\begin{tabular}{|c|c|c|c|c|c|c|c|c|}
\hline \multirow[b]{2}{*}{ Year } & \multicolumn{4}{|c|}{ Dates of sowing } & \multicolumn{4}{|c|}{$\mathrm{N}$ rates $\left(\mathrm{kg} \mathrm{ha}^{-1}\right)^{*}$} \\
\hline & D1 & D2 & D3 & D4 & No & N1 & N2 & N3 \\
\hline 2014 & 18 Sep & 14 Oct & $10 \mathrm{Nov}$ & & $0+0$ & $0+50$ & $0+100$ & \\
\hline 2015 & 25 Sep & 16 Oct & $14 \mathrm{Nov}$ & & $0+0$ & $25+25$ & $25+75$ & $25+125$ \\
\hline 2016 & 26 Sep & $10 \mathrm{Oct}$ & $28 \mathrm{Oct}$ & $08 \mathrm{Nov}$ & $0+0$ & $25+25$ & $25+75$ & $25+125$ \\
\hline
\end{tabular}

${ }^{*} \mathrm{~N}$ rates separated as pre-plant+top-dress; pre-plant $\mathrm{N}$ was applied shortly before sowing (on the same day); top-dress N applications at 4 March 2015; 20 February 2016; 27 February 2017.

$\mathrm{N}$ fertilizer rates were used and in 2015 and 2016 four (Table 1). The experimental unit consisted of six rows (50 cm between rows) $5 \mathrm{~m}$ long.

The soil was mouldboard ploughed and cultivated twice before sowing. In the experimental plots, $44 \mathrm{~kg} \mathrm{P} \mathrm{ha}^{-1}$ (as superphosphate $18 \% \mathrm{P}_{2} \mathrm{O}_{5}$ ) and $83 \mathrm{~kg} \mathrm{~K} \mathrm{ha}^{-1}$ (as potassium chloride $60 \% \mathrm{~K}_{2} \mathrm{O}$ ) were applied each year shortly before sowing as well as pre-plant $\mathrm{N}$ (as ammonium nitrate, $20.5 \% \mathrm{~N}$ ) in the corresponding plots of the trials of 2015 and 2016. A residual herbicide (active ingredient, napropamide, $450 \mathrm{~g} \mathrm{dm}^{-3}$ ) was also applied every year before sowing. Herbicide and fertilizers were incorporated with the last pass of the cultivator, which simultaneously left open small grooves $50 \mathrm{~cm}$ apart. Thereafter, $1.25 \mathrm{~g}$ of seed were distributed in each row (equivalent to $5 \mathrm{~kg} \mathrm{seed} \mathrm{ha}^{-1}$ ) and buried by hoe to 1 to $3 \mathrm{~cm}$ depth. The hybrid 'PT225' (Pioneer) was the cultivar used in this study. The crop was rainfed managed and after sowing no other cropping practices were needed, excluding top-dress $\mathrm{N}$ application added as an experimental variable. No pest or disease problems were detected during the three years of study.

In the vegetative phase in March $4^{\text {th }} 20$ February $2015^{\text {th }} 2016$, and 27 February 2017, samples of $1 \mathrm{~m}$ linear or $0.5 \mathrm{~m}^{2}$ (50 cm between rows) were taken to evaluate above ground dry matter (DM) and $\mathrm{N}$ recovery. Top-dress $\mathrm{N}$ was applied shortly after these samples had been taken. The phenological stages of the plants at the time of top-dress $\mathrm{N}$ application varied somewhat with sowing date and year, but the plants were classified between the phenological stage 30 (beginning of stem elongation; no internodes 'rosete') and 34 (four visible extended internodes), according to the extended $\mathrm{BBCH}$ (Biologische Bundesanstalt, Bundessortnamt and CHemical industry) scale of Meier (2001), a system for a uniform coding of phenological growth stages of all mono- and dicotyledonous species. A month to a month and a half later (April $22^{\text {nd }} 23$ March $2015^{\text {rd }} 2016$, and 29 March 2017) the above described sampling procedure was repeated. In 22 April 2015, phenological stages varied from 61 (10\% of flowers on main raceme) to 66 (80\% of flowers on main raceme) depending on the sowing date. In 23 March 2016 and 29 March 2017, the phenological stages varied respectively from 55 [individual flower buds (main inflorescence) visible but still closed] to 59 (yellow bud) and 57 [individual flower buds (secondary inflorescence) visible but still closed] to 61 (10\% of flowers on main raceme). At harvest, samples of $4 \mathrm{~m}^{2}$ ( 4 inner rows, $2 \mathrm{~m}$ long) were collected. These samples were air dried for 2 to 3 weeks protected with an anti-bird net for more complete dehydration. Subsequently the field samples were weighed (seed + straw) and threshed with a wooden stick, the seed being separated from the straw with sieves and air stream. After cleaning, the seed was weighed and by difference to the total weight, the DM of the straw was obtained.

Subsamples of straw and seed were oven dried at $70^{\circ} \mathrm{C}$ to constant weight, and with the moisture content, adjustments were made on DM yield of seed and straw. The straw subsamples were thereafter ground and, together with the seed, subsamples analyzed for total $\mathrm{N}$ concentration. $\mathrm{N}$ concentration in tissues was determined by steam distillation and acid titration in an automated Kjeldahl analyzer (Kjeltec ${ }^{\text {TM }}$ 8400, Foss, Denmark). In 2017 subsamples of seed were used for the determination of the oil content. Oil seed content was determined by the Soxhlet method, which consists of the extraction of the oil from the seeds by the action of the solvent petroleum ether. The oil content is subsequently determined gravimetrically. 
During the growing season the phenological stages of oilseed rape were periodically assessed by using the extended $\mathrm{BBCH}$ scale. In addition to the registration of the phenological stages in important dates, such as the application of the top-dress $\mathrm{N}$, as afore mentioned, special attention was given to the growth stage 5 (inflorescence emergence) and 6 (flowering), since they correspond to a period in which the phenological stages of the plants of all the dates of sowing tend to synchronize.

Data analysis was carried out using JMP software. In the split-plot design, sowing dates (main plots), $\mathrm{N}$ rates (subplots) and interaction (sowing dates $\mathrm{x} \mathrm{N}$ rates) were treated as fixed and blocks [sowing dates] as random factors. After ANOVA examination, the means with significant differences $(a<0.05)$ were separated by the Tukey HSD test. Based on DM yield and N recovery in the above ground biomass, two indices of $\mathrm{N}$ use efficiency were estimated:

- Apparent N Recovery (ANR, \%) = 100×(plant N uptake in fertilized plots-plant $\mathrm{N}$ uptake in the control)/N applied as a fertilizer; and

- Agronomic Efficiency or $\mathrm{N}$ productivity $\left(\mathrm{AE}, \mathrm{kg} \mathrm{kg}^{-1}\right)=(\mathrm{DM}$ yield in fertilized plots-DM yield in the control)/ $\mathrm{N}$ applied as a fertilizer

\section{Results}

On the first sampling date, in late February or early March, the above ground DM yields approached $5 \mathrm{t} \mathrm{ha}^{-1}$ for the first sowing date of each year and abruptly decreased as the sowing date was delayed (Figure 2). In 2017, DM yield approached $3 \mathrm{t} \mathrm{ha}^{-1}$ for the second sowing date, but the results of the third and fourth sowing dates were very low. In 2016 and 2017, the pre-plant application of $25 \mathrm{~kg} \mathrm{~N} \mathrm{ha}^{-1}$ had a non-significant effect on the DM yield over the control treatment for any of the sowing dates and years, although there was a tendency for a slight increase in the average values. The results of $\mathrm{N}$ recovery in above ground biomass were similar to those of DM yield with an abrupt decrease as the sowing date was delayed. Pre-plant applied $\mathrm{N}$ had a more consistent effect on $\mathrm{N}$ recovery than on DM yield due to the increase in $\mathrm{N}$ concentration in plant tissues, but the mean values never showed significant differences. On these first sampling dates, performed prior to a top-dress $\mathrm{N}$ application, there were recorded $147.5,128.1$ and $211.5 \mathrm{~kg} \mathrm{~N} \mathrm{ha}^{-1}$ in the above ground biomass, respectively in 2015, 2016 and 2017.

Dry matter yields in the early spring, five to six weeks after top-dress $\mathrm{N}$ applications, showed a very clear decreasing cascade pattern as the sowing date was delayed (Figure 3). DM yields were significantly higher on the first sowing dates and decreased sequentially till the later sowing date. Within each date of sowing, $\mathrm{N}$ applied as top-dressing significantly increased the DM yield. On this sampling date, DM yield reached 15.1, 11.2 and $9.1 \mathrm{t} \mathrm{ha}^{-1}$ respectively in 2015, 2016 and 2017, in the best combination of sowing date and $\mathrm{N}$ rate.

The pattern reported for DM yield (Figure 3) was also observed for $\mathrm{N}$ recovery (Figure 4), i.e. significantly more $\mathrm{N}$ was recovered from the earlier sowing dates and from the fertilizer treatments receiving higher $\mathrm{N}$ rates. The effect of top-dress $\mathrm{N}$ applied in $\mathrm{N}$ recovery was even more marked than in DM yield since the application of $\mathrm{N}$ increased tissue $\mathrm{N}$ concentration. There was also found significant interaction between sowing date and $\mathrm{N}$ rate in 2015 and 2016 as a result of the greater response to top-dress applied $\mathrm{N}$ by the earliest sowed plants. On this sampling date, the earliest sowing dates and the fertilizer treatments receiving the higher $\mathrm{N}$ rates gave $\mathrm{N}$ recoveries of 382.6, 241.2, and $377.7 \mathrm{~kg} \mathrm{ha}^{-1}$, respectively in 2015, 2016 and 2917.

The cascade pattern observed in the DM yield in the middle of the growing season remained until harvest (Figure 5). Earlier sowing produced significantly more seed than delayed sowing. $\mathrm{N}$ rate also significantly increased seed yield. In the most productive combinations of sowing date and $\mathrm{N}$ rate, mean seed yields of 3.4, 6.2 and $4.6 \mathrm{t} \mathrm{ha}^{-1}$ were reached, respectively in 2015, 2016, and 2017. In the less productive combination of those factors, only $0.3,0.3$, and $1.0 \mathrm{t} \mathrm{ha}^{-1}$ of seed were recorded. 

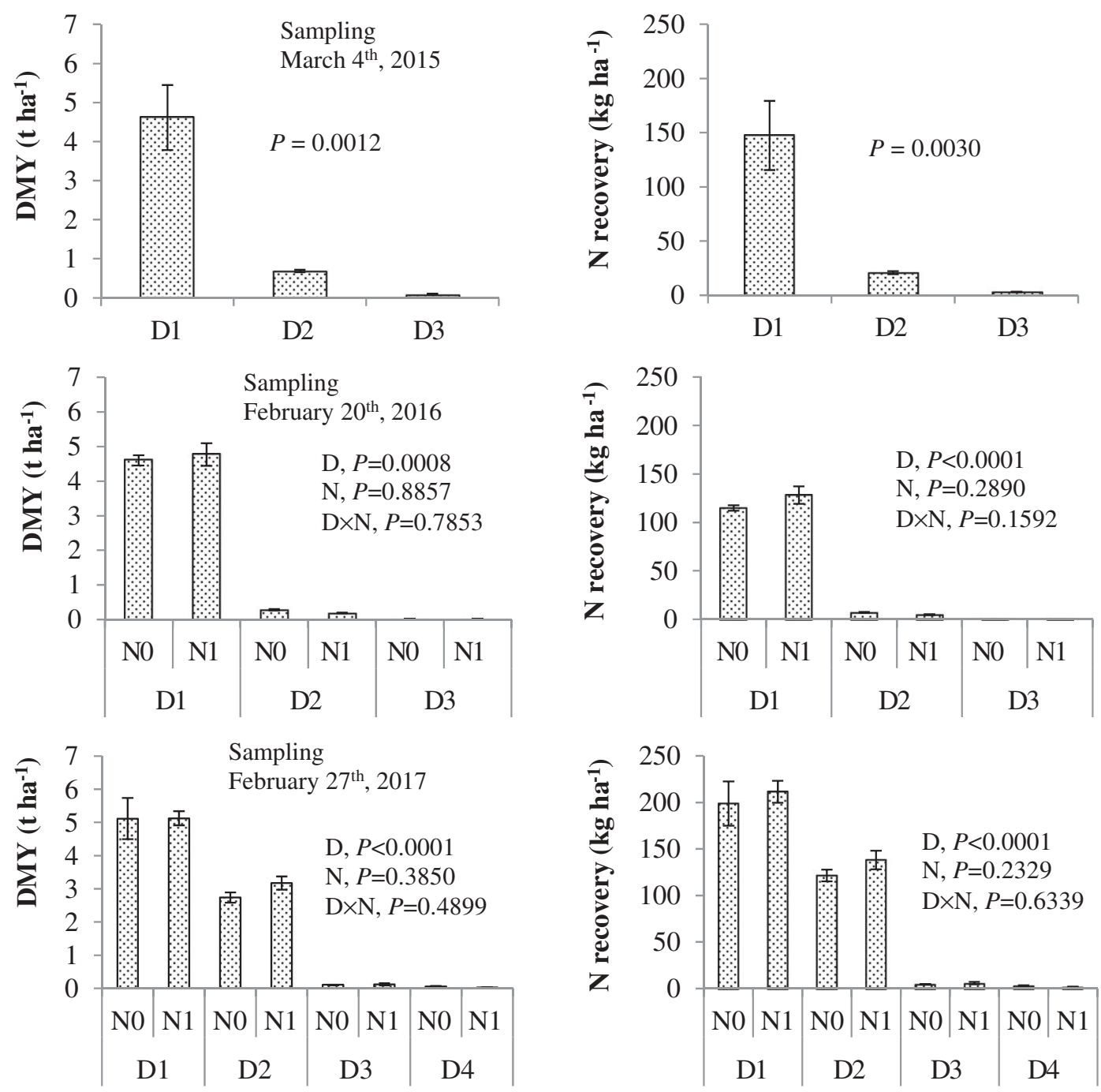

Figure 2. Dry matter yield (DMY) and N recovery as a function of sowing date (D1, 18 September 2014, 25 September 2015 , 26 September 2016; D2, 14 October 2014, 16 October 2015, 10 October 2016; D3, 10 November 2014, 14 November 2015, 28 October 2016; D4, 8 November 2016) and preplant $\mathrm{N}$ (N0, $0 \mathrm{~kg} \mathrm{~N} \mathrm{ha}^{-1} ; \mathrm{N} 1,25 \mathrm{~kg} \mathrm{~N} \mathrm{ha}^{-1}$ ) application from a sampling performed before top-dress $\mathrm{N}$ application. Analysis of variance, $\mathrm{P}$ (Prob > F), D (date of sowing), N (N rate), and D $\times \mathrm{N}$ (interaction). Error bars are the confidence intervals of the means $(a=0.05)$.

$\mathrm{N}$ recovery in the above ground biomass showed the pattern observed for seed yield with significant decrease from the first to the last sowing dates (Figure 6). $\mathrm{N}$ recovery also significantly increased with $\mathrm{N}$ rate within each sowing date. The significant interaction between sowing date and $\mathrm{N}$ rate found in 2015 and 2016 reflects the higher response of the earliest sowed plants to topdress $\mathrm{N}$ in comparison to the response of the plants sown latter in the autumn. In the sequence of the three years of study (20,015-2017), total above ground biomass (seed+straw) recovered 216.3, 251.7, and $304.7 \mathrm{~kg} \mathrm{~N} \mathrm{ha}^{-1}$ and 23.0, 14.3, and $46.2 \mathrm{~kg} \mathrm{~N} \mathrm{ha}^{-1}$ as the maximum and minimum average values of the combination of sowing date and $\mathrm{N}$ rate.

Based on the most productive $\mathrm{N}$ fertilization rates within each sowing date and year, the average seed production loss over time was estimated in absolute and in relative terms. There was found to be a significant linear $(P<0.001)$ decrease with both approximations, although the 

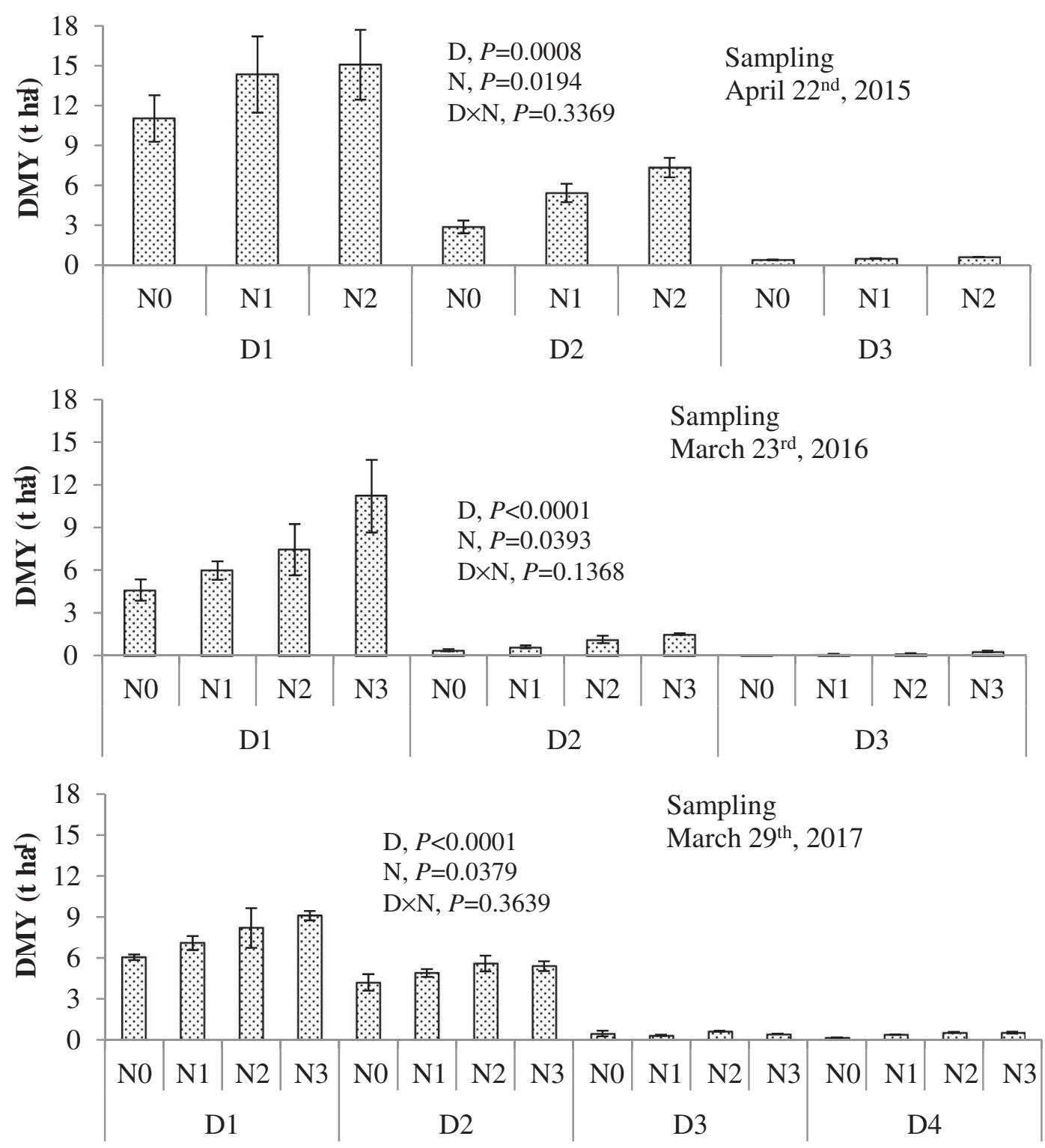

Figure 3. Dry matter yield (DMY) as a function of sowing date (D1, 18 September 2014, 25 September 2015, 26 September 2016; D2, 14 October 2014, 16 October 2015, 10 October 2016; D3, 10 November 2014, 14 November 2015, 28 October 2016; D4, 8 November 2016) and fertilizer treatment (preplant + top-dress N) (N0, $0 \mathrm{~kg} \mathrm{~N} \mathrm{ha}^{-1} ; \mathrm{N1}, 50 \mathrm{~kg} \mathrm{~N} \mathrm{ha}^{-1}$; $\mathrm{N} 2,100 \mathrm{~kg} \mathrm{~N} \mathrm{ha}^{-1} ; \mathrm{N} 3,150 \mathrm{~kg} \mathrm{~N} \mathrm{ha}^{-1}$ ) from a sampling performed five to six weeks after top-dress $\mathrm{N}$ application. Analysis of variance, $\mathrm{P}$ (Prob $>\mathrm{F}), \mathrm{D}$ (date of sowing), $\mathrm{N}(\mathrm{N}$ rate), and $\mathrm{D} \times \mathrm{N}$ (interaction). Error bars are the confidence intervals of the means $(a=0.05)$.

expression of the results in relative terms provided a higher coefficient of determination $\left(R^{2}=0.89\right)$ since the variability in seed yield associated with each agricultural year was removed (Figure 7$)$. The daily loss of seed production was estimated as $68.9 \mathrm{~kg} \mathrm{ha}^{-1}$ or $1.53 \%$ in absolute and relative terms, respectively, which means weekly losses of $482.3 \mathrm{~kg} \mathrm{ha}^{-1}$ or $10.7 \%$ when the sowing is delayed from mid-September to mid-November.

Some key phenological states occurred at slightly different dates in different years depending on environmental variables. Using as an example the experiment of $2016 / 2017$, in which four 

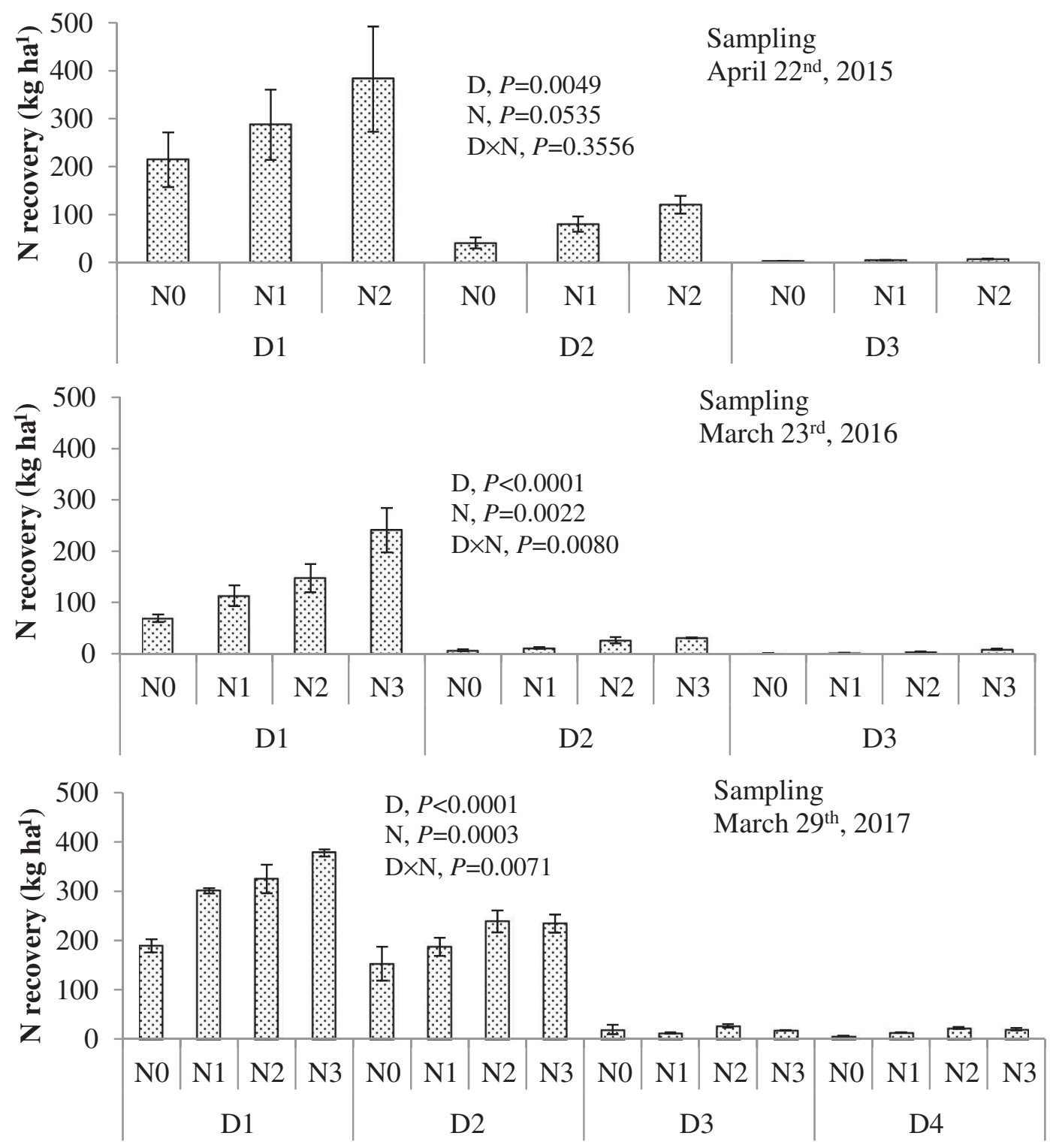

Figure 4. N recovery as a function of sowing date (D1, 18 September 2014, 25 September 2015, 26 September 2016; D2, 14 October 2014, 16 October 2015, 10 October 2016; D3, 10 November 2014, 14 November 2015, 28 October 2016; D4, 8 November 2016) and fertilizer treatment (preplant + top-dress N) (N0, $0 \mathrm{~kg} \mathrm{~N} \mathrm{ha}^{-1} ; \mathrm{N} 1,50 \mathrm{~kg} \mathrm{~N} \mathrm{ha}^{-1} ; \mathrm{N} 2,100 \mathrm{~kg} \mathrm{~N} \mathrm{ha}{ }^{-1} ; \mathrm{N} 3$, $150 \mathrm{~kg} \mathrm{~N} \mathrm{ha}^{-1}$ ) from a sampling performed five to six weeks after top-dress $\mathrm{N}$ application. Analysis of variance, $\mathrm{P}$ (Prob $\left.>\mathrm{F}\right)$, $\mathrm{D}$ (date of sowing), $\mathrm{N}(\mathrm{N}$ rate), and $\mathrm{D} \times \mathrm{N}$ (interaction). Error bars are the confidence intervals of the means $(a=0.05)$.

different sowing dates were performed, spaced over 44 days (the first on 26 September and the last on 8 November), there was found to be a difference of only 10 days at the beginning of flowering between the first and the last sowing dates, with the flowering finishing almost at the same time on all sowing dates. Thus, according to Meier's phenological scale (Meier 2001), the phase 61 (10\% of flowers on main raceme open, main raceme elongating) occurred on April $1^{\text {st }}$ in the plots sown on September $26^{\text {th }}$, and on April $11^{\text {th }}$ in the plots sown on November $8^{\text {th }}$. The phase 69 (end of flowering) occurred practically at the same time between 15 to 20 May for all the sowing dates. 

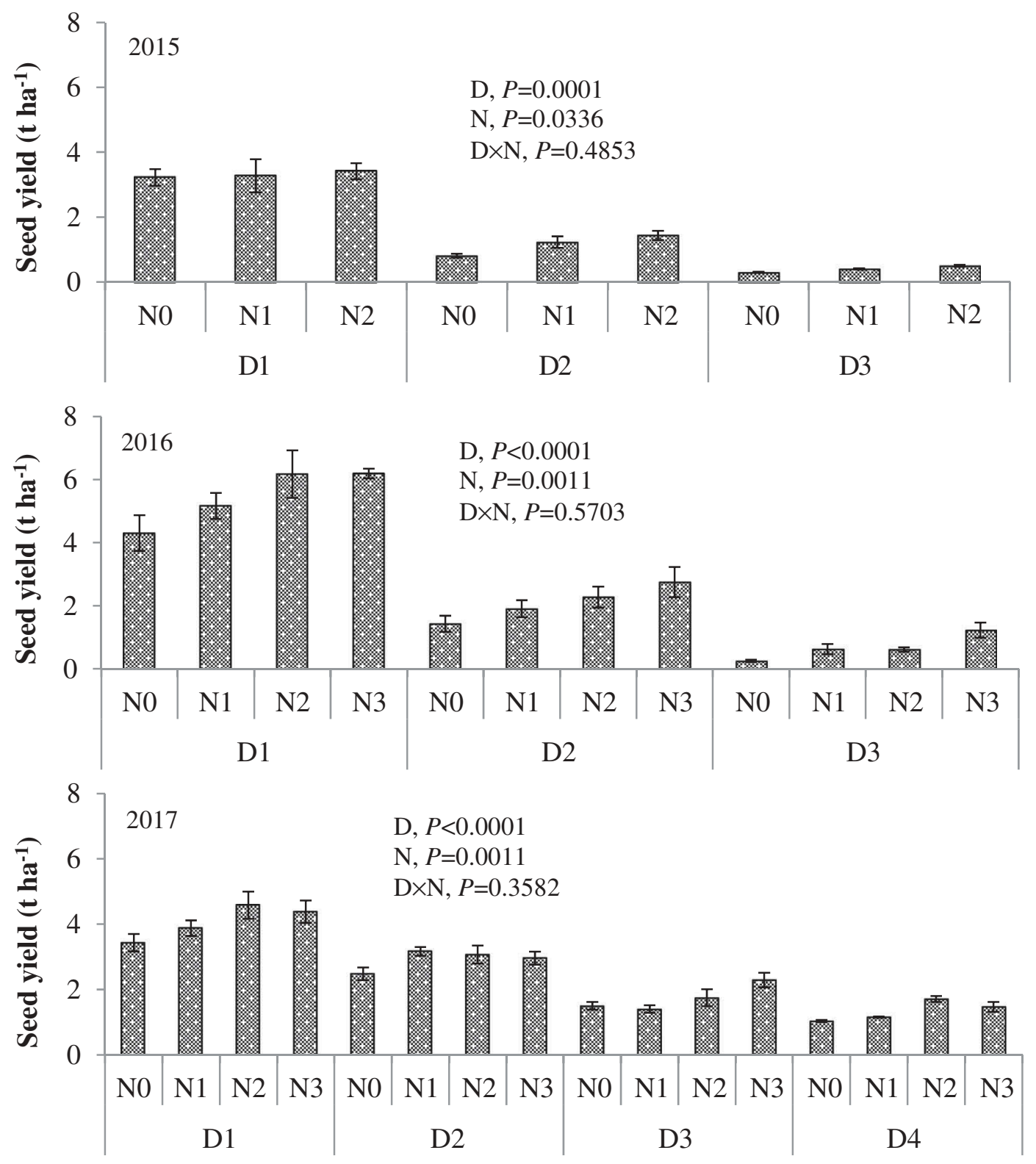

Figure 5. Seed yield as a function of sowing date (D1, 18 September 2014, 25 September 2015, 26 September 2016; D2, 14 October 2014, 16 October 2015, 10 October 2016; D3, 10 November 2014, 14 November 2015, 28 October 2016; D4, 8 November 2016) and fertilizer treatment (preplant + top-dress N) (N0, $0 \mathrm{~kg} \mathrm{~N} \mathrm{ha}^{-1} ; \mathrm{N} 1,50 \mathrm{~kg} \mathrm{~N} \mathrm{ha}^{-1} ; \mathrm{N} 2,100 \mathrm{~kg} \mathrm{~N} \mathrm{ha}{ }^{-1} ; \mathrm{N} 3$, $150 \mathrm{~kg} \mathrm{~N} \mathrm{ha}^{-1}$ ). Analysis of variance, $\mathrm{P}$ (Prob $>\mathrm{F}$ ), D (date of sowing), $\mathrm{N}(\mathrm{N}$ rate), and $\mathrm{D} \times \mathrm{N}$ (interaction). Error bars are the confidence intervals of the means $(\alpha=0.05)$.

Seed oil content significantly varied among sowing dates but not among $\mathrm{N}$ rates (Figure 8). It seems that although the last sowing dates produced much less seed, it appeared to be more concentrated in oil. $\mathrm{N}$ rate seemed to decrease seed oil content, although the results have never been significantly different. Seed oil content varied from $17.7 \%$ (D2, N3) to $25.7 \%$ (D3, N0).

In this crop only is the seed removed from the system at harvest, which means that a significant part of $\mathrm{N}$ applied as a fertilizer remains in the system immobilized in straw. In general terms, as the 

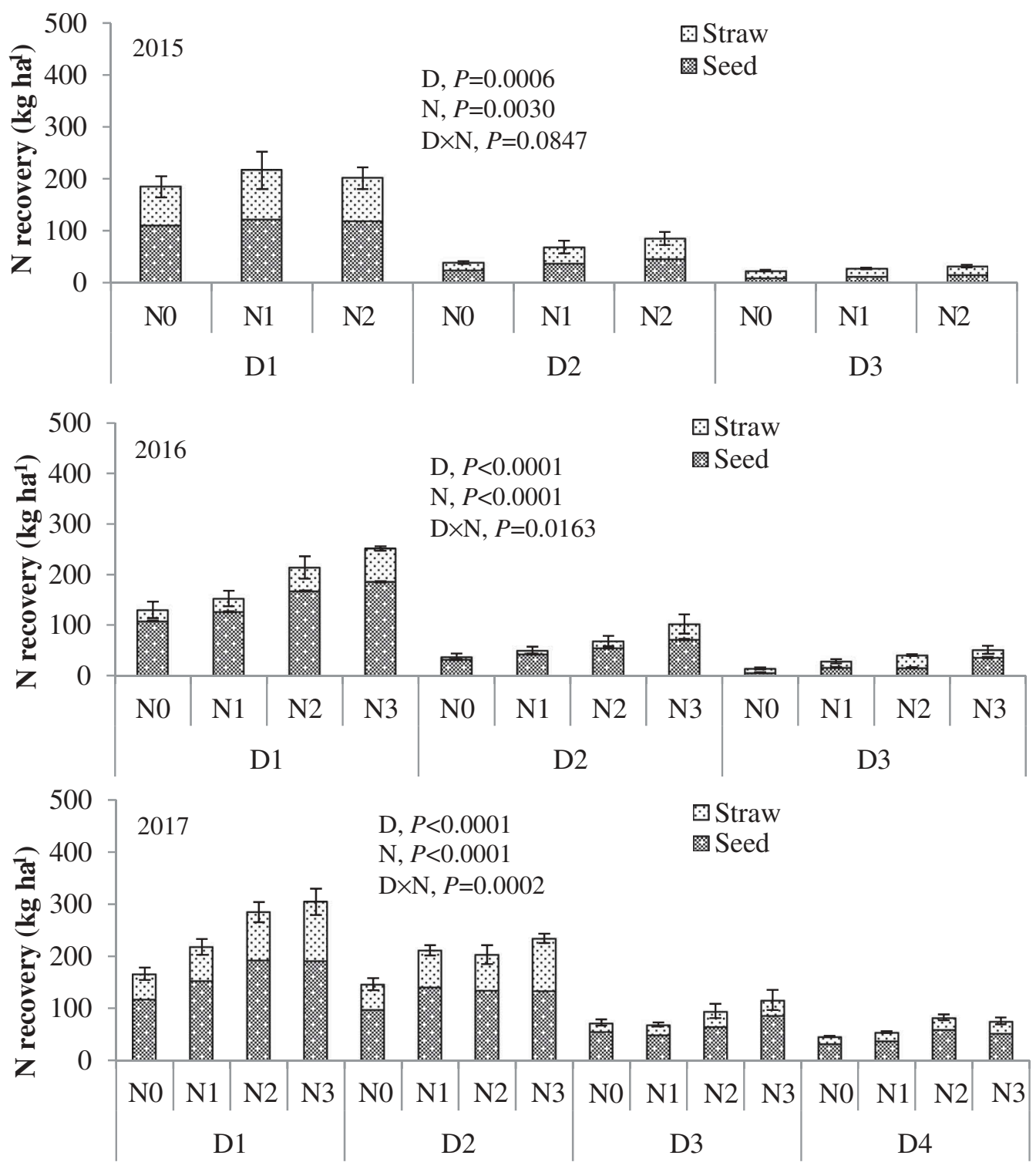

Figure 6. N recovery as a function of sowing date (D1, 18 September 2014, 25 September 2015, 26 September 2016; D2, 14 October 2014, 16 October 2015, 10 October 2016; D3, 10 November 2014, 14 November 2015, 28 October 2016; D4, 8 November 2016) and fertilizer treatment (preplant + top-dress N) (N0, $0 \mathrm{~kg} \mathrm{~N} \mathrm{ha}^{-1} ; \mathrm{N} 1,50 \mathrm{~kg} \mathrm{~N} \mathrm{ha}^{-1} ; \mathrm{N} 2,100 \mathrm{~kg} \mathrm{~N} \mathrm{ha}{ }^{-1} ; \mathrm{N} 3$, $150 \mathrm{~kg} \mathrm{~N} \mathrm{ha}{ }^{-1}$ ) separated in seed and straw. Analysis of variance, $\mathrm{P}$ (Prob $>\mathrm{F}$ ), D (date of sowing), $\mathrm{N}(\mathrm{N}$ rate), and $\mathrm{D} \times \mathrm{N}$ (interaction) for total $\mathrm{N}$ recovery (straw + seed). Error bars are the confidence intervals of the means of the total $\mathrm{N}$ recovery (straw + seed) $(a=0.05)$.

date of sowing is delayed a smaller percentage of the applied $\mathrm{N}$ is removed in the seed or in the total biomass (Table 2 ). In the first sowing dates, apparent $\mathrm{N}$ recovery greatly varied among years and $\mathrm{N}$ rates. In the total biomass, apparent $\mathrm{N}$ recovery was sometimes higher than $100 \%$ meaning that the crop had taken up more $\mathrm{N}$ from the soil than that was applied as a fertilizer. As the sowing dates were delayed, apparent $\mathrm{N}$ recovery decreased to very low values, including negative values in a particular situation, meaning that in this case the plants of the fertilized treatment had taken up less $\mathrm{N}$ than non-fertilized plants. 


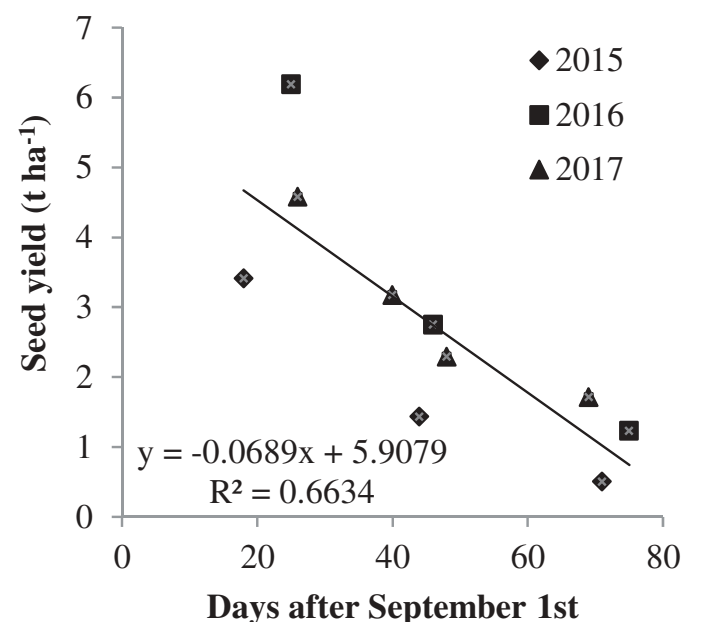

Days after September 1st

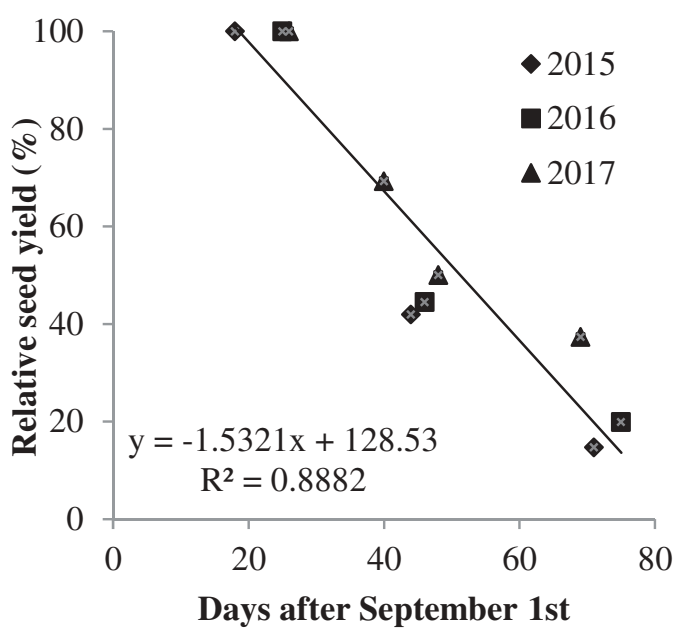

Figure 7. Average seed yield in the most productive $\mathrm{N}$ fertilized treatment for each sowing date of the three years of the experiment expressed as a) $\mathrm{tha}^{-1}$, or b) percentage (\%) after expressed the latter in relation to the production of the first sowing date of each year.

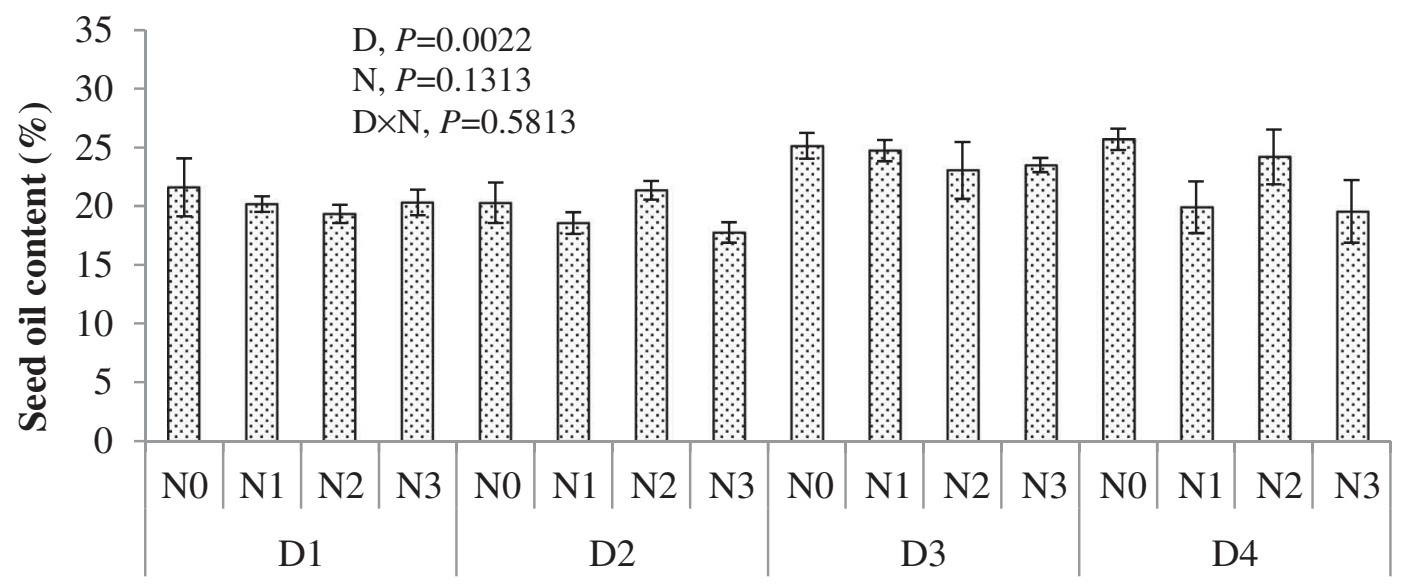

Figure 8. Seed oil content as a function of sowing date (D1, 26 September 2016; D2, 10 October 2016; D3, 28 October 2016; D4, 8 November 2016) and fertilizer treatment (preplant + top-dress N) (N0, $0 \mathrm{~kg} \mathrm{~N} \mathrm{ha}^{-1} ; \mathrm{N} 1,50 \mathrm{~kg} \mathrm{~N} \mathrm{ha}^{-1} ; \mathrm{N} 2,100 \mathrm{~kg} \mathrm{~N} \mathrm{ha}{ }^{-1} ; \mathrm{N} 3$, $150 \mathrm{~kg} \mathrm{~N} \mathrm{ha}^{-1}$ ). Analysis of variance, $\mathrm{P}$ (Prob > F), D (date of sowing), $\mathrm{N}$ ( $\mathrm{N}$ rate), and $\mathrm{D} \times \mathrm{N}$ (interaction). Error bars are the confidence intervals of the means $(a=0.05)$.

Agronomic efficiency or $\mathrm{N}$ productivity reduced with $\mathrm{N}$ rate and with sowing date whether the concept is applied to seed yield or total biomass (Table 3). In 2016, and in the treatment receiving $50 \mathrm{~kg} \mathrm{~N} \mathrm{ha}^{-1}$, more than $100 \mathrm{~kg}$ seed was produced per $\mathrm{kg} \mathrm{N}$. In the three years of study and also for the treatment of $50 \mathrm{~kg} \mathrm{~N} \mathrm{ha}^{-1}$, total biomass per unit of $\mathrm{N}$ applied exceeded $300 \mathrm{~kg}$. In the last sowing dates the production of seed per unit of $\mathrm{N}$ applied was frequently lower than $20 \mathrm{~kg}$.

\section{Discussion}

At late February/early March, shoot DM yield reached values of about $5 \mathrm{t} \mathrm{ha}^{-1}$ in the plots of the first sowing dates with an abrupt decrease for the following ones. At this sampling date, the plants of the earliest sowings had recovered $147.5,128.1$ and $211.5 \mathrm{~kg} \mathrm{~N} \mathrm{ha}^{-1}$, respectively in 2015, 2016 
Table 2. Apparent $\mathrm{N}$ recovery (\%) in the seed and in all the above ground biomass (Total) as a function of sowing date and $\mathrm{N}$ rate. [Apparent $\mathrm{N}$ recovery $(\%)=100 \times($ plant $\mathrm{N}$ uptake in fertilized plots-plant $\mathrm{N}$ uptake in the control)/ $\mathrm{N}$ applied as a fertilizer]

\begin{tabular}{|c|c|c|c|c|c|c|c|c|c|}
\hline \multirow[b]{3}{*}{ Year } & \multirow[b]{3}{*}{$\begin{array}{c}\mathrm{N} \text { rates } \\
\left(\mathrm{kg} \mathrm{ha}^{-1}\right)\end{array}$} & \multicolumn{8}{|c|}{ Date of sowing } \\
\hline & & \multicolumn{2}{|c|}{ D1 } & \multicolumn{2}{|c|}{ D2 } & \multicolumn{2}{|c|}{ D3 } & \multicolumn{2}{|c|}{ D4 } \\
\hline & & Seed & Total & Seed & Total & Seed & Total & Seed & Total \\
\hline \multirow[t]{2}{*}{2015} & 50 & 22.9 & 63.9 & 26.1 & 59.5 & 6.1 & 9.0 & & \\
\hline & 100 & 8.0 & 16.8 & 21.7 & 46.0 & 6.0 & 8.7 & & \\
\hline \multirow[t]{3}{*}{2016} & 50 & 36.7 & 46.7 & 20.6 & 25.5 & 20.3 & 28.2 & & \\
\hline & 100 & 59.4 & 83.7 & 22.6 & 31.5 & 9.8 & 26.5 & & \\
\hline & 150 & 51.8 & 81.0 & 26.1 & 43.3 & 19.6 & 24.5 & & \\
\hline \multirow[t]{3}{*}{2017} & 50 & 70.5 & 111.2 & 85.3 & 141.8 & -11.6 & -7.1 & 10.7 & 18.3 \\
\hline & 100 & 74.5 & 129.3 & 36.0 & 62.2 & 9.4 & 25.2 & 26.5 & 38.8 \\
\hline & 150 & 48.6 & 102.9 & 23.8 & 67.4 & 20.8 & 30.8 & 12.9 & 21.5 \\
\hline
\end{tabular}

Table 3. Agronomic efficiency or productivity of $\mathrm{N}\left(\mathrm{kg} \mathrm{DM} \mathrm{kg}^{-1} \mathrm{~N}\right)$ applied to seed and to all the above ground biomass (Total) as a function of sowing date and $\mathrm{N}$ rate. [Agronomic efficiency or productivity of $\mathrm{N}\left(\mathrm{kg} \mathrm{kg}^{-1}\right)=(\mathrm{DM}$ yield in fertilized plots-DM yield in the control)/ $\mathrm{N}$ applied as a fertilizer].

\begin{tabular}{|c|c|c|c|c|c|c|c|c|c|}
\hline \multirow[b]{3}{*}{ Year } & \multirow[b]{3}{*}{$\begin{array}{c}\left(\mathrm{kg} \mathrm{ha}^{-1}\right) \\
\mathrm{N} \text { rates }\end{array}$} & \multicolumn{8}{|c|}{ Date of sowing } \\
\hline & & \multicolumn{2}{|c|}{ D1 } & \multicolumn{2}{|c|}{ D2 } & \multicolumn{2}{|c|}{ D3 } & \multicolumn{2}{|c|}{ D4 } \\
\hline & & Seed & Total & Seed & Total & Seed & Total & Seed & Total \\
\hline \multirow[t]{2}{*}{2015} & 50 & 65.5 & 308.2 & 24.5 & 134.6 & 8.0 & 70.0 & & \\
\hline & 100 & 34.1 & 156.7 & 14.3 & 85.6 & 5.0 & 39.0 & & \\
\hline \multirow[t]{3}{*}{2016} & 50 & 103.3 & 357.3 & 38.0 & 121.3 & 12.4 & 28.2 & & \\
\hline & 100 & 61.7 & 213.3 & 22.7 & 90.7 & 6.1 & 26.5 & & \\
\hline & 150 & 41.3 & 141.3 & 18.3 & 77.3 & 8.2 & 24.5 & & \\
\hline \multirow[t]{3}{*}{2017} & 50 & 77.5 & 318.7 & 63.3 & 286.7 & 28.0 & 114.7 & 23.1 & 120.0 \\
\hline & 100 & 45.8 & 180.4 & 30.7 & 147.7 & 17.5 & 77.3 & 17.1 & 76.0 \\
\hline & 150 & 29.2 & 119.6 & 19.7 & 91.6 & 15.2 & 57.8 & 9.8 & 48.9 \\
\hline
\end{tabular}

and 2017 and, as reported for DM yield, there was also observed a dramatic decrease in $\mathrm{N}$ recovered for the later sowings. The ability of rapeseed to uptake high amounts of $\mathrm{N}$ in the early growth stages has previously been reported which makes it a valuable catch crop during autumn (Dejoux et al. 2000; Rossato et al. 2001; Bouchet et al. 2016). In the conditions of this experiment, rapeseed may be such an important catch crop by absorbing residual $\mathrm{N}$ from the soil in the autumn, but only if sowing is done early. In comparison to other crops such as cereals, the great development of rapeseed in the autumn makes it a more effective $\mathrm{N}$ catch crop. In similar growing conditions, Rodrigues et al. (2002) found reduced efficacy of triticale ( $\times$ Triticosecale) in recovering $\mathrm{N}$ in the autumn as it only accumulates significant amounts of biomass from the spring when stem extension starts.

In the second sampling date, five to six weeks after the top-dress $\mathrm{N}$ application, the values of $\mathrm{N}$ recovered in shoots of the plants from the first dates of sowing and the most fertilized treatments were 382.6, 241.1 and $377.7 \mathrm{~kg} \mathrm{ha}^{-1}$, respectively, in 2015, 2016 and 2017. This result proves the high ability of rapeseed to absorb and store $\mathrm{N}$ in the shoots during the vegetative stage, as reported in other research (Colnenne et al. 1998; Dejoux et al. 2000; Bouchet et al. 2016). The huge rosette formed during the autumn represents a significant pool of photoassimilates that the plants from late sowing do not have. The above ground DM reached 15.1, 11.2 and $9.1 \mathrm{t} \mathrm{ha}^{-1}$ in the most productive treatments. Top-dress $\mathrm{N}$ fertilization increased average DM yield within each sowing date but did not allow the plants of later sowings to reach the amounts of biomass found in the plants of the earliest sowing dates. Sieling et al. (2017) also reported results from 
a trial with rapeseed where additional $\mathrm{N}$ supply was only partially able to compensate for poor autumn shoot and tap root growth.

Late-sowed plants have a shorter growing cycle. Plants sown 42 days later begin flowering with only a delay of 10 days and end flowering only five days later. The shift from vegetative to reproductive stages that occurs before the end of winter does not allow late-sowed plants to recover, even though growing conditions remain somewhat favourable, due to competition for photoassimilates between the vegetative and reproductive plant parts. From floral initiation a change in source-sink relationships occurs, and the vegetative plant segments switch from being sink organs to source organs (Bouchet et al. 2016). Thus, the greater amount of biomass accumulated during autumn and winter is converted to higher seed yield with significantly higher values for the first sowing date, followed by the second, third and fourth in 2017. The delay in the sowing date caused significant loss of seed production. Estimates based on the most productive fertilizer treatments showed that daily loss of seed production was $68.9 \mathrm{~kg} \mathrm{ha}^{-1}$ from the earliest sowing dates of mid-September to mid-November. $\mathrm{N}$ fertilization increased seed production within each sampling date, however late dates have never reached the productivity level of the early dates. The pattern of seed production was maintained for $\mathrm{N}$ recovered in the seed, and in all the above ground biomass, although significant differences had been more frequent due to the increased tissue $\mathrm{N}$ concentration with $\mathrm{N}$ rate.

Seed yield also varied greatly among years. In the most productive combinations of sowing dates and $\mathrm{N}$ rates, mean seed yields were 3.4, 6.2 and $4.6 \mathrm{t} \mathrm{ha}^{-1}$, respectively in 2015, 2016 and 2017. Meteorological data (Figure 1) can provide a good explanation for this result. Accumulated rainfall from January to May amounted to $143.3,588.8$ and $327.6 \mathrm{~mm}$, respectively in 2015, 2016 and 2017, a variation similar to that was found in seed yield. If the estimates of productivity loss were made from relative seed yield to minimize the effect of annual variation on seed yield, a daily reduction of $1.53 \%$ was found from mid-September to mid-November.

The seed oil content also varied with the sowing date although significantly higher values were recorded in the later sowing, likely because the later sowing gave rise to less branched plants with a greater proportion of seed production based on the main raceme. Zang et al. (2012) found that higher densities tend to give rise to higher seed oil content with the result being attributed to the higher proportion of seed coming from the main raceme. The increase in the $\mathrm{N}$ rate appears to be associated with a slight reduction in the oil content in the seed although the differences were not statistically significant and should be associated with the increase in protein content, since the oil plus the protein content tend to be constant in the seed of the rape (Brennan et al. 2000). In previous studies a significant reduction was found between $\mathrm{N}$ rate and seed oil content (Šiaudinis and Butkute 2013; Varényiová and Ducsay 2016). In any case, the oil content in the seeds was lower than that recorded by Brennan et al. (2000), which probably is a reflection of the very poor humidity conditions late in the growing seasons during grain filling (Figure 1).

Apparent $\mathrm{N}$ recovery varied greatly within each sowing date and for the different $\mathrm{N}$ rates, likely because the index was sensitive to growing conditions. If on the one hand the spring of 2016 was the wettest and thus presented a higher risk of $\mathrm{N}$ loss by leaching and denitrification, on the other hand the humidity favoured plant growth, increasing the opportunity for root uptake of $\mathrm{N}$. On the other hand, as the date of sowing was delayed, apparent $\mathrm{N}$ recovery was markedly reduced by lowering the potential for $\mathrm{N}$ uptake. In this species $\mathrm{N}$ recovery tends to be less than $60 \%$ (Bouchet et al. 2016), although in this study apparent $N$ recovery was often above that value for the first sowing dates. The result might be related to the fact that the preceding crop was a mixture of small grains and legumes which may have increased soil available $\mathrm{N}$, and the mild temperatures of the region (Figure 1) should have favor the mineralization of the N-rich organic substrate.

The productivity of $\mathrm{N}$ was much higher for the earlier sowing dates compared to the later ones. Although this species tends to show a lower productivity per unit of $\mathrm{N}$ available than cereals (Sylvester-Bradley and Kindred 2009), values of $103 \mathrm{~kg}$ seed $\mathrm{kg}^{-1} \mathrm{~N}$ were found for the first sowing 


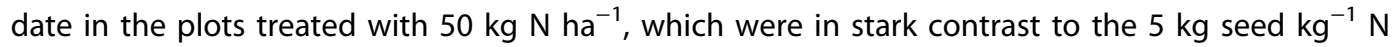
obtained to the third sowing date of 2015 when $100 \mathrm{~kg} \mathrm{~N} \mathrm{ha}^{-1}$ were applied.

\section{Conclusions}

In the conditions of these experiments, rapeseed proved to be an excellent catch crop but only if sown early. $\mathrm{N}$ recovery in above ground biomass in late February/early March, before top-dress $\mathrm{N}$ application, varied from 128 to $212 \mathrm{~kg} \mathrm{~N} \mathrm{ha}^{-1}$.

Seed yield was very dependent on the date of sowing varying from 3.4 to $6.2 \mathrm{t} \mathrm{ha}^{-1}$ in the first sowing date to 0.3 to $1.0 \mathrm{t} \mathrm{ha}^{-1}$ in the last sowing date. The daily loss in seed production was $68.9 \mathrm{~kg} \mathrm{ha}^{-1}$ (or $482.3 \mathrm{~kg} \mathrm{ha}^{-1}$ per week) or $1.53 \%$ (or $10.7 \%$ per week). It seems clear that in Mediterranean conditions a fundamental rule for growing rapeseed is to sow as early as possible probably having as a reference point the first autumn rains.

Apparent $\mathrm{N}$ recovery and agronomic efficiency indices did not confirm the general opinion that this crop displays low $\mathrm{N}$ use efficiency. These results did not show a pattern of low values of $\mathrm{N}$ use efficiency but rather a great variability depending on the growing conditions. The results also showed that large amounts of $\mathrm{N}$ remain in the system after harvest, in the straw, making rapeseed an important preceding crop for high $\mathrm{N}$-demanding species such as cereals.

\section{Disclosure statement}

No potential conflict of interest was reported by the authors.

\section{Funding}

The authors are grateful to the Foundation for Science and Technology (FCT, Portugal) and FEDER under Programme PT2020 for financial support to CIMO (UID/AGR/00690/2013).

\section{ORCID}

M. Ângelo Rodrigues (iD) http://orcid.org/0000-0002-5367-1129

Margarida Arrobas (iD http://orcid.org/0000-0002-4652-485X

\section{References}

Berrocoso J, Rojas O, Liu Y, Shoulders J, González-Vega J, Stein H. 2015. Energy concentration and amino acid digestibility in high protein canola meal, conventional canola meal, and soybean meal fed to growing pigs. J Anim Sci. 93(5):2208-2217.

Bouchet A-S, Laperch A, Bissuel-Belaygue C, Snowdon R, Nesi N, Stahl A. 2016. Nitrogen use efficiency in rapeseed. A Review. Agron Sustain Dev. 36:38.

Brennan RF, Mason MG, Walton GH. 2000. Effect of nitrogen fertilizer on the concentrations of oil and protein in canola (Brassica napus) seed. J Plant Nutr. 23:339-348.

Colnenne C, Meynard JM, Reau R, Justes E, Merrien A. 1998. Determination of a critical dilution curve for winter oilseed rape. Ann Bot. 81:311-317.

Dejoux J-F, Recous S, Meynard J-M, Trinsoutrot I, Leterne P. 2000. The fate of nitrogen from winter-frozen rapeseed leaves: mineralization, fluxes to the environment and uptake by rapeseed crop in spring. Plant Soil. 218:257-272.

Din J, Khan SU, Ali I, Gurmani AR. 2011. Physiological and agronomic response of canola varieties to drought stress. J Anim Plant Sci. 21:78-82.

FAOSTAT (Food and Agriculture Organization of the United Nations). 2018. Crops; [Accessed 2018 Feb]. http://www. fao.org/faostat/en/\#data/QC.

Fismes J, Vong PC, Guckert A, Frossard E. 2000. Influence of sulfur on apparent N use efficiency: yield and quality of oilseed rape (Brassica napus L.) grown on a calcareous soil. Eur J Agron. 12:127-141. 
Gu X-B, Li Y-N, Du Y-D. 2017. Optimized nitrogen fertilizer application improves yield, water and nitrogen use efficiencies of winter rapeseed cultivated under continuous ridges with film mulching. Ind Crops Prod. 109:233-240.

Guerrero A. 1999. Cultivos herbáceos extensivos. 6th ed. Madrid (Spain): Mundi-Prensa.

Hamzei J. 2011. Seed, oil, and protein yields of canola under combinations of irrigation and nitrogen application. Agron J. 103:1152-1158.

Hamzei J, Soltani J. 2012. Deficit irrigation of rapeseed for water-saving: effects on biomass accumulation, light interception and radiation use efficiency under different $\mathrm{N}$ rates. Agric Ecosyst Environ. 155:153-160.

Havlin JL, Tisdale SL, Nelson WL, Beaton JD. 2014. Soil fertility and fertilizers. An introduction to nutrient management. New Jersey: Pearson, Inc.

IUSS Working Group WRB. 2014. World reference base for soil resources 2014. International soil classification system for naming soils and creating legends for soil maps. World Soil Resources Reports No. 106. FAO: Rome.

Johnson BL, McKay KR, Schneiter AA, Hanson BK, Schatz BG. 1995. Influence of sowing date on canola and crambe production. J Prod Agric. 8:594-599.

Körbitz W. 1995. Utilization of oil as a biodiesel fuel. In: Kimber D, McGregor DI, editors. Brassica oilseeds, production and utilization. Wallingford (UK): Cab International; p. 353-371.

Kuai J, Sun Y, Zhou M, Zhang P, Zuo Q, Wu J, Zhou G. 2016. The effect of nitrogen application and planting density on the radiation use efficiency and the stem lignin metabolism in rapeseed (Brassica napus L.). Field Crops Res. 199:89-98.

Leach JE, Stevenson HJ, Rainbow AJ, Mullen LA. 1999. Effects of high plant populations on the growth and yield of winter oilseed rape (Brassica napus L.). J Agric Sci. 132:173-180.

Leiva-Candia DE, Ruz-Ruiz MF, Pinzi S, Garcia-Ruiz JR, Dominguez J, Garcia IL, Dorado MP. 2013. Influence of nitrogen fertilization on physical and chemical properties of fatty acid methyl esters from Brassica napus oil. Fuel. 111:865-871.

Li H, Cong RH, Ren T, Li XK, Ma CB, Zheng L, Zhang Z, Lu JW. 2015. Yield response to N fertilizer and optimum N rate of winter oilseed rape under different soil indigenous $N$ supplies. Field Crops Res. 181:52-59.

Little TM, Hills FJ. 1978. Agricultural experimentation: design and analysis. New York (USA): John Wiley \& Sons, Inc.

Meier U. 2001. Growth stages of mono- and dicotyledonous plants. BBCH Monographs, 2nd ed. BBCH Publ (Germany): Federal Biological Research Centre for Agriculture and Forestry.

Németh T, Máthé-Gáspár G, Radimszki L, Györi Z. 2009. Nitrogen and sulfur content of canola grown on a calcareous Chernozem soil. Commun Soil Sci Plant Anal. 40:825-834.

Norouzi M, Toorchi M, Salekdeh GH, Mohammadi SA, Neyshabouri MR, Aharizad S. 2008. Effect of water deficit on growth, grain yield and osmotic adjustment in rapeseed. J Food Agri Environ. 6:312-318.

Ozer H. 2003. Sowing date and nitrogen rate effects on growth, yield and yield components of two summer rapeseed cultivars. Eur J Agron. 19:453-463.

Pinzi S, Gandia LM, Arzamendi G, Ruiz JJ, Dorado MP. 2011. Influence of vegetable oils fatty acid composition on reaction temperature and glycerides conversion to biodiesel during transesterification. Bioresour Technol. 102:1044-1050.

Pouzet A. 1995. Agronomy. In: Kimber D, McGreger DI, editors. Brassica oilseeds, production and utilization. CAB International, Wallingford (UK); p. 65.

Rathke GW, Behrens T, Diepenbrock W. 2006. Integrated nitrogen management strategies to improve seed yield, oil content and nitrogen efficiency of winter oilseed rape (Brassica napus L.): a review. Agric Ecosyst Environ. 117 (2-3):80-108.

Rathke GW, Christen O, Diepenbrock W. 2005. Effects of nitrogen source and rate on productivity and quality of winter oilseed rape (Brassica napus L.) grown in different crop rotations. Field Crops Res. 94(2-3):103-113.

Rodrigues MA, Almeida A, Ferreira J, Ribeiro T, Arrobas M. 2011. Response of rapeseed to nitrogen fertilisation in a Mediterranean environment. Proc. 4th International congress on energy and environment engineering and management; May 26/27; Mérida (Spain).

Rodrigues MA, Arrobas M, Almeida A. 2014. Agronomic performance of five rapeseed varieties grown for biodiesel in the Northeast of Portugal. Proc. International Congress on Water, Waste and Energy Management; July 16-18; Porto, Portugal.

Rodrigues MA, Coutinho J, Martins F. 2002. Efficacy and limitations of triticale as nitrogen catch crop in a Mediterranean environment. Eur J Agron. 17(3):155-160.

Rodrigues MA, Ferreira I, Arrobas M. 2010. Studies on rapeseed winter cultivars, nitrogen rates and seeding depths in Northeastern Portugal. Rev Ciênc Agrár. XXXIII(2):27-39.

Rodrigues MA, Maia L, Rocha R, Ferreira IQ, Arrobas M, Almeida A. 2013. Studies on nitrogen rates, sowing dates and cultivars of rapeseed in Northeastern Portugal. Proc. 5th International Congress on Energy and Environment Engineering and Management; July 17-19; Lisbon.

Rossato L, Lainé P, Ourry A. 2001. Nitrogen storage and remobilization in Brassica napus L. during the growth cycle: nitrogen fluxes within the plant and changes in soluble protein patterns. J Exp Bot. 52(361):1655-1663. 
Sepaskhah AR, Tafteh A. 2012. Yield and nitrogen leaching in rapeseed field under different nitrogen rates and water saving irrigation. Agric Water Manag. 112:55-62.

Šiaudinis G, Butkute B. 2013. Response of spring oilseed rape seed yield and quality to nitrogen and sulfur fertilization. Commun Soil Sci Plant Anal. 44:145-157.

Sieling K, Böttcher U, Kage H. 2017. Sowing date and N application effects on tap root and above-ground dry matter of winter oilseed rape in autumn. Eur J Agron. 83:40-46.

Sieling K, Christen O. 1997. Effect of preceding crop combination and $\mathrm{N}$ fertilization on yield of six oilseed rape cultivars (Brassica napus L.). Eur J Agron. 7:301-306.

Sylvester-Bradley R, Kindred DR. 2009. Analyzing nitrogen responses of cereals to prioritize routes to the improvement of nitrogen use efficiency. J Exp Bot. 60(7):1939-1951.

Takashima NE, Rondanini DP, Puhl LE, Miralles DJ. 2013. Environmental factors affecting yield variability in spring and winter rapeseed genotypes cultivated in the southeastern Argentine Pampas. Eur J Agron. 48:88-100.

Taylor AJ, Smith CJ. 1992. Effect of sowing date and seeding rate on yield components of irrigated canola (Brassica napus L.) grown on a red/brown earth in South-Eastern Australia. Aust J Agric Res. 43(7):1629-1641.

Varényiová M, Ducsay L. 2016. Effect of increasing spring doses of nitrogen on yield and oil content in seeds of oilseed rape (Brassica napus L.). Acta fytotechn zootechn. 19(2):29-34.

Wang N, Qian W, Suppanz I, Wei L, Mao B, Long Y, Meng J, Muller AE, Jung C. 2011. Flowering time variation in oilseed rape (Brassica napus L.) is associated with allelic variation in the FRIGIDA homologue BnaA.FRI.a. J Exp Bot. 62 (15):5641-5658.

Wang R, Cheng T, Hu L. 2015. Effect of wide-narrow row arrangement and plant density on yield and radiation use efficiency of mechanized direct-seeded canola in Central China. Field Crops Res. 172:42-52.

Zhang SJ, Liao X, Zhang CL, Xu HJ. 2012. Influences of plant density on the seed yield and oil content of winter oilseed rape (Brassica napus L.). Ind Crops Prod. 40:27-32. 